\title{
V Jugoslaviji ne poznamo stavk, imamo pa nekaj prekinitev dela: stavke v socialistični Sloveniji
}

\author{
Jurij Hadalin \\ UP FHŠ, Oddelek za zgodovino \\ Inštitut za novejšo zgodovino \\ jurij.hadalin@fhs.upr.si
}

\section{Uvod}

Delo obravnava fenomen stavke $\mathrm{v}$ času socialistične ureditve $\mathrm{v}$ Sloveniji. Ker je bila stavka $\mathrm{v}$ svojem bistvu $\mathrm{v}$ nasprotju $\mathrm{z}$ načeli nove socialistične družbe, še bolj pa z zapletenim družbenopolitičnim sistemom delavskega samoupravljanja, ki so ga v Jugoslaviji razvijali od leta 1950 dalje, so delavske stavke predstavljale resno zadrego za politični režim. Stavkovni valovi v vzhodnem bloku, usmerjeni tudi proti družbenopolitični ureditvi, kot so se zgodili v Vzhodni Nemčiji in na Poljskem leta 1953, so bili fenomen, ki ni prestopil jugoslovanskih meja. Stavka je bila nato od šestdesetih let naprej stalno prisoten pojav, ki pa je bil povezan predvsem s vprašanjem življenjskega standarda. Kot kaže raziskava iz zgodnjih osemdesetih let, je bil pojav stavk medsebojno povezan $\mathrm{z}$ gospodarskim razvojem. Običajno so se stavke začele na najrazvitejših območjih, zato ni čudno, da je prva registrirana stavka v Jugoslaviji izbruhnila v trboveljskem premogovniku leta 1958, trend pa se je nato pomikal proti manj razvitim območjem. Pojav stavke bo zato obravnavan $\mathrm{v}$ širšem časovnem loku in umeščen $\mathrm{v}$ družbenopolitični razvoj s pomočjo sočasnih družboslovnih analiz, temeljil pa bo na poročilih o stavkah iz treh različnih obdobij.

\section{Jugoslovanski samoupravni eksperiment in stavke}

U livarni, u vročini, kjer ti pamet odpove, proizvodnja je obstala sredi delovnega dne. 
"Vsak nam kamandira, an nam mitinge drži, vsi so strašn kunštn, ja delama pa mi,« godrnjali so livarji, nekdo pa rekel je: "Pubi, konc je šihta, pubi usidma se!« Prihitel je šef izmene: "Ja fantje, kva je to? Zakva ste se usedel, a vam je slabo?

Kurjač je vzel kladivo: „Da nauš ti slab zdej ratu, vsed se v kot pa tih bod, da te nam ošlatau." Prihitel je delovodja, a tudi on je obsedel, in direktor $v$ beli srajci je na premogu čepel. Tako livarji priredili so za poslovodni organ, $v$ vročini svojih plavžev informativni dan. In so zvišali jim plače, vse se srečno je izšlo, zgodba ni šla $v$ tisk in škandala ni bilo,

A še danes vsi v fabriki ob čikpavzah se zgroze, kadar rečejo livarji: "Pubi, usidma se." (Mlakar 1992)

Zgoraj navedena pesem slovenskega kantavtorja Iztoka Mlakarja, ki je izšla poleti 1992, je verjetno najboljši prikaz tega, kako je do samoupravnih prekinitev dela v Sloveniji prihajalo, torej spontano. In ni jih bilo malo, le njihova magnituda navadno ni bila prav velika, tisk pa o njih ni poročal. Toda za razumevanje tega, kako je deloval jugoslovanski socialistični eksperiment v praksi, je potrebno najprej pojasniti nekaj pojmov (Prinčič 1992). V Jugoslaviji premoženje ni bilo državno, temveč družbeno. Z njim so nominalno samoupravno upravljali neposredni proizvajalci. In če je bila v drugih evropskih ljudskih demokracijah/socialističnih državah vpeljana oblika diktature proletariata, kjer je bilo gospodarstvo centralno vodeno, je bila situacija v Jugoslaviji nekoliko drugačna, vsaj na papirju.

Izvor jugoslovanskega eksperimenta je potrebno iskati v letu 1948 in jugoslovansko-sovjetskem razkolu. $\mathrm{V}$ prvem povojnem obdobju je Jugoslavija dosledno uvajala sistem ljudske demokracije, ki se je nato pod vplivom različnih dejavnikov prelevila $\mathrm{v}$ socialistično demokracijo. Zanjo je bil značilen drugačen pogled na državo, njeno upravo in njeno lastnino. Bistvena razlika med ljudsko in socialistično demokracijo je bilo razumevanje vloge države in položaja njenega upravnega aparata. Če je imel državni aparat $\mathrm{v}$ ljudski demokraciji odločujočo vlogo, je to pomenilo, da sta bili država in njena administracija vsemogočni. V nasprotju s tem je bil v socialistični demokraciji poudarek na deetatizaciji, katere namen je bil slabitev države in njenega upravnega aparata, vključno s politično stranko. Končni 
cilj tega procesa je bil odmrtje oziroma odprava države. Kot način odmiranja države naj bi nastopala tudi lastnina proizvajalnih sredstev. Ta so bila sprva podržavljena, nato pa $\mathrm{v}$ skladu $\mathrm{z}$ razdržavljanjem prenesena $\mathrm{v}$ last vse družbe (vseh državljanov oz. »delovnih ljudi«) kot t. i. družbena lastnina.

Državo so jugoslovanski teoretiki obravnavali kot izraz razredne družbe in tako so gledali tudi na lastnino. Ideal jim je tako predstavljala družbena lastnina, ki je $z$ uvedbo delavskega samoupravljanja v letu 1950 nastala iz splošnega ljudskega premoženja, s katerim je upravljala država. $Z$ vpeljavo delavskega samoupravljanja so proizvajalna sredstva upravljali delovni kolektivi. Nasprotje tega, se pravi sistem, kakršen je obstajal na t. i. Vzhodu, so dojemali kot »državni kapitalizem«. Jugoslovanski novi moto »Tovarne delavcem! « se je tako izkristaliziral, preko misli Karla Marxa o »asociaciji neposrednih proizvajalcev«, v idejo delavskega samoupravljanja, v kateri naj bi imeli delavci preko svojih izvoljenih predstavnikov možnost sodelovanja $s$ predlogi in tudi $\mathrm{z}$ nadzorom nad poslovanjem podjetja, $\mathrm{v}$ katerem so bili zaposleni.

Implementacija zamisli o predaji tovarn $\mathrm{v}$ upravljanje delavcem je potekala hitro, vendar nekako iz ozadja, saj o tem ni razpravljal noben visok državni ali partijski forum, izvedba je padla na pleča sindikatov in gospodarskega sveta. Z vzpostavitvijo delavskih svetov se položaj direktorja, ki ga je imenovalo ministrstvo in je bil prvi državni birokrat podjetja, ni praktično v ničemer spremenil. Naloga delavskega sveta je bila, »da budno spremlja delo in pomaga napredku proizvodnje in dela v podjetju«. Delavski sveti, v katere so zaposleni volili svoje predstavnike, so razpravljali ne samo o vodenju ali poslovanju podjetja, temveč predvsem o delovnem redu v podjetju, boljši organizaciji dela in delovni disciplini (Čepič 2011, 269-71).

$S$ časom je jugoslovanski samoupravni model zorel in se bolj ali manj uspešno soočil s procesi, ki so bili centralno vodenim socialističnim gospodarstvom neznani, od pojava brezposelnosti (ki jo je deloma blažil proces začasnega izvoza delovne sile na Zahod, t. i. gastarbeiterji) do podjetij, ki so propadla. Dokončno je dozorel s sprejetjem zvezne in republiških ustav leta 1974 in svoj vrhunec dosegel s sprejetjem t. i. »delavske ustave«, to je Zakona o združenem delu (UL SFRJ, 3. 12. 1976, 53-764). To je bil kompleksen zakon, ki je obsegal 671 členov ter je urejal vsa družbenoekonomska razmerja, katerih temelj je bilo združeno delo. Predvsem pa je jugoslovansko družbo spremenil z uvedbo kompleksnih in tedanjemu, kaj pa šele današnjemu, rodu popolnoma nerazumljivih vzorcev delovanja in terminologije (Čepič 
2005, 1099-101). Gospodarska podjetja so se po novem imenovala temeljne organizacije združenega dela, ki so se združevale $\mathrm{v}$ kompleksnejše sestavljene organizacije združenega dela. Za našo tematiko je pomembno predvsem to, da je v času »zrelega samoupravljanja« le-to sicer pomenilo veliko interakcijo zaposlenih s poslovnimi politikami, a tudi nemalo težav in grotesknih okoliščin. Požiralo je ogromne količine časa, saj je bilo potrebno za vsako odločitev, ki je posegala $\mathrm{v}$ dohodke, sklicevati sestanke in zbore delavcev. V delavskih svetih, kjer so bili zastopani tudi »neposredni proizvajalci«, so ti velikokrat svoje pravice razumeli kot dolžnost nastopanja proti vodstvu podjetja ter nasprotovanja poslovnim odločitvam. Vse to je potekalo med delovnim časom in zmanjševalo storilnost, podjetja pa so se bolj kot $\mathrm{s}$ proizvodnjo ukvarjala $\mathrm{z}$ vprašanji lastne organizacije. Težave so bile tudi s sprejemanjem t. i. samoupravnih sporazumov, kjer so se bile uspešne organizacije prisiljene povezovati s slabše stoječimi, kar je hitro pripeljalo do tega, da so se uspešnejši tozdi še vedno obnašali kot podjetja, še posebej pri vprašanju denarja (Brečko idr. 1973, 23-24). Medsebojno uničevanje tozdov je pripeljalo do njihovega postopnega tihega ukinjanja, čeprav je organizacija obstala vse do leta 1989 in velikih gospodarskih reform zadnjega jugoslovanskega premierja Anteja Markovića (Prinčič 2005, 1101-104).

A vendar se poraja vprašanje, kako je lahko v tako kompleksnem socialno-ekonomskem modelu, kjer so bili delavci uradno hkrati delodajalci in delojemalci, proizvajalci in upravljavci, in kjer so razpolagali z rezultati svojega dela ter sprejemali odločitve o vseh pomembnih vprašanjih svojega podjetja, prihajalo do stavk.

\section{2. Čas sproščanja konfliktov}

A vrnimo se najprej na vprašanje, kdaj so se stavke začele pojavljati. Uradno so zaznane relativno pozno, saj je bila prva uradna prekinitev dela zaznana šele leta $1958 \mathrm{v}$ trboveljskem premogovniku. Zgoraj omenjeni procesi uvajanja drugačne različice socializma so ob očitnem pomanjkanju »nezaželenih neposrednih sovjetskih vplivov« pripomogli k temu, da je bilo v sicer težkih petdesetih letih vzdušje med delavstvom mirno (Kavčič idr. 1991, 75) ${ }^{\mathrm{I}}$. Težko torej povlečemo vzporednice $\mathrm{z}$ dogajanji v vzhodnem blo-

$1 \quad$ V raziskovalnem poročilu o stavkah v Jugoslaviji, ki je bilo izdano leta 1991, so avtorji zapisali, da je bila trboveljska stavka prva povojna stavka, kljub temu da so jo nekateri zgodnejši avtorji označevali zgolj kot prvo registrirano stavko. A o čem podobnem ni drugih zapisov oz. so avtorji dopuščali možnost, da so bile stavke že pred tem, a niso bile registrirane oziroma konflikti niso prerasli v stavko. 
ku, ki so ga v letu 1953 pretresale velike stavke, predvsem na Poljskem in v Nemški demokratični republiki. Ob tem ni nepomembno omeniti pojava, ki je pretresel Jugoslavijo, namreč upor v Cazinu, t. i. »cazinska buna«. Izbruhnil je v ruralnem predelu Bosne in Hercegovine, povod zanj pa je bil nezadovoljstvo s prisilnim odkupom kmetijskih proizvodov, ki ga je zahtevala centralna oblast zaradi potreb po izpolnjevanju petletnega gospodarskega načrta. To je tudi čas, ko je Jugoslavija poskušala biti »bolj papeška od papeža« in je v letih 1948-1949 začela velik proces kolektivizacije ter ustanavljanja kmečkih zadrug po sovjetskem vzoru. V letu 1950 se je sicer tem gospodarsko in socialno neučinkovitim metodam odpovedala, a cazinskih dogodkov 6. maja 1950 ni uspela preprečiti. To je bil dejansko načrtovan oborožen upor proti režimu, ki ga je lokalno vodstvo s pomočjo milice in pripadnikov Jugoslovanske ljudske armade krvavo zatrlo. Ni pa to bila stavka $\mathrm{v}$ pravem pomenu besede, saj ni imela urbanega značaja in se je uprlo ruralno prebivalstvo, ki je v tem času nosilo največje breme (Kržišnik Bukić 1991).

$\mathrm{V}$ pregledu stavkovnih gibanj $\mathrm{v}$ Jugoslaviji so petdeseta leta označena kot »brezkonfliktno obdobje«. O tem je sicer že bilo govora v prvem delu besedila, a dejstvo je, da: »čeprav je povojna Jugoslavija izšla iz oborožene faze revolucije kot najradikalnejšega konflikta, so dominantni akterji tako kot $\mathrm{v}$ drugih državah, ki so izvedle socialistično revolucijo, negirali konflikt kot gibalo družbenega razvoja. Na podlagi predpostavk o odpravljenosti razredne razklanosti družbe, zagotovljenosti vladajočega položaja delavskega razreda in njegovih zgodovinskih interesov, so tudi onemogočali kakršnakoli odstopanja in manifestiranje potencialnih konfliktov. Do konflikta je lahko prišlo le $\mathrm{z}$,ostanki starega sistema', $\mathrm{z}$,notranjimi in zunanjimi sovražniki', medtem ko so konflikti, ki so izhajali iz obstoječih socialnih nasprotij, ostajali v latentni obliki. $\mathrm{K}$ temu je prispevala tudi institucionalna struktura, ki je bila izvedena iz temeljnih socioloških orientacij in ni vključevala nikakršnih mehanizmov za izražanje socialnih konfliktov. Začetek socialnih konfliktov ni sovpadal s pomembnejšimi institucionalnimi ali socialnoekonomskimi spremembami $\mathrm{v}$ danem trenutku, temveč je rezultat nekaterih sprememb $\mathrm{v}$ ideološki koncepciji in $\mathrm{v}$ institucionalni strukturi, do katerih je privedel spor z Informbirojem, ki pa je hkrati začasno celo okrepil netolerantnost do razlik in konfrontacij znotraj sistema. Vrednote, ki označujejo ,brezkonfliktni' sistem, tako niso dominirale le v času ,administrativnega socializma', temveč tudi po institucionalizaciji delavskega samoupravljanja» (Kavčič idr. 1991, 76-77). 
A konec petdesetih let je prišlo do »sproščanja konfliktov«, kar po mnenju zgoraj navedenih avtorjev pomeni, da so se »dominantni akterji« pričeli zavedati, da nasprotja v socializmu niso samo rezultat delovanja »ostankov preteklosti«, temveč tudi rezultat nasprotij v obstoječi družbenoekonomski strukturi (Kavčič idr. 1991, 81).

Prva registrirana stavka v socialistični Jugoslaviji, znana kot »trboveljski dogodki«, se je torej zgodila v prvih dneh januarja 1958. Izbruhnila je natančno tam, kjer je po teoretičnih osnovah tudi morala, $v$ najrazvitejšem delu Jugoslavije, v rudarskem Zasavju. To je bil velik udarec za tedanje republiško vodstvo, saj so veliki rudniki rjavega premoga predstavljali simbol predvojnega revolucionarnega boja. Stavkovna tradicija $v$ teh krajih je bila dolga in še danes je ostal izraz za ta predel Slovenije, ki ga poznamo tudi pod imenom "rdeči revirji«. Rudarji in ostalo od rudnikov odvisno prebivalstvo so po daljšem času stabilizacije pričeli postajati vse bolj nezadovoljni s svojim osebnim položajem. Nekdanji direktor rudnika v Zagorju je tako dejal: »Rudarji so od leta 1945 naprej delali skoraj nepretrgoma, delovnih dni na leto je bilo 320 in več. Pogoji za delo so bili slabi, delo je bilo izključno ročno in je zahtevalo izredne fizične napore. $V$ prvih letih so imeli rudarji relativno dobre zaslužke. Imeli so tudi posebne dodatke, kot je bila jamska karta za živila, ki je omogočala relativno velik nakup moke, masti in mesa po zelo nizkih cenah. $\mathrm{V}$ začetku 5o-tih let so bile živilske karte ukinjene, hrana se je močno podražila, rudarske plače pa so ostale iste. Zvezna administracija, strogo pod kontrolo politike, je trdno držala zamrznjene zelo nizke cene premoga. Tako so se na osnovi cenene energije ustvarjala sredstva za izgradnjo nove industrije na novih lokacijah ter za njeno uspešno poslovanje.« (Skopec 2007, 27) Iz poročila Centralnega komiteja Zveze Komunistov Slovenije, ki je obravnavalo razmere v Zasavju, je mogoče razbrati, da se je ekonomski položaj rudnika Trbovlje-Hrastnik v letu pred stavko močno poslabšal. Začele so pojemati zaloge premoga, njegova cena je bila že nekaj let maksimirana, cena potrošnega materiala pa je naraščala. V kombinaciji s prestrukturiranjem jugoslovanskega gospodarstva, ko se je vrednostna lestvica panog pričela spreminjati in je bil vse manjši poudarek na razvoju rudarske in težke industrije, je rudnik ostal brez investicijskih sredstev, ki jih je nujno potreboval za širitev. Po sprva ugodnih finančnih projekcijah za leto 1957 je tako rudnik nameraval rudarjem izplačati približno 2 in pol plači dodatka. Ker pa sredstev iz splošnega investicijskega fonda ni pridobil, je bilo vodstvo rudnika primorano novo naložbo financirati iz lastnih sredstev. Delavci s tem niso bili dovolj seznanjeni in 29. no- 
vembra, ob državnem prazniku, rudnik dodatkov ni bil sposoben izplačati. Politične in druge vodstvene strukture so se osredotočile na vprašanje neusklajenih cen premoga in intervencije na republiški in zvezni ravni, medtem pa je sindikat pričel izgubljati zaupanje delavcev.

D. Skopec v svoji študiji izpostavlja vlogo republiškega funkcionarja, med drugim v tistem trenutku tudi sekretarja CK KPS in lokalnega delegata Mihe Marinka, ki naj bi bil glavni krivec za zadrževanje cen premoga, o katerih je odločala zvezna vlada. To naj bi počel $v$ dogovoru $z$ vodstvom zasavskega rudnika, da bi zaviral inflacijo. Marinko je ob svojih intervencijah med stavko doživel to, česar v povojnem času jugoslovanski politiki niso bili vajeni - bil je izžvižgan in tako rekoč fizično napaden. Vodstvo rudniki in visoki republiški funkcionarji so medtem vedeli, da bo potrebno na zvezni ravni nekaj ukreniti, začeli so pritiskati na zvezno vlado, ki naj bi na seji 14. januarja 1958 razpravljala o zvišanju cen zasavskega premoga. A ta informacija do delavcev, ki dodatkov niso prejeli niti ob novem letu, očitno ni prišla, dogodki so pričeli prehitevati politično vodstvo.

Popoldan 13. januarja 1958 je bil v trboveljskem rudniku sestanek sindikata. Tu je bilo »ob dokaj demagoških nastopih posameznikov« ugotovljeno, da je rudnik novo leto začel s precejšnjo izgubo, ki je napovedano splošno povišanje cen premoga ni moglo pokriti, ter da so bile delegacije $\mathrm{v}$ Beogradu neuspešne. Sočasno je potekal tudi sestanek trboveljskega SZDL, kjer je bila problematika rudnika ravno tako »na tapeti«. Vmes je iz rudnika prišla informacija, da je prišlo do stavke. Ta se je kuhala, težko pa bi rekli, da organizirano pripravljala, že od 29. novembra, po rudniku so se pričele pojavljati parole, na katere pa nihče iz vodstva ali političnih organov ni odreagiral, ker so menili, da imajo položaj pod kontrolo. Kot se rado zgodi, je med rudarji kmalu pričela krožiti tudi govorica, da bodo do nadaljnjega prejemali le še 8o-odstotne plače. Vloga rudniškega vodstva je $v$ teh dogodkih nekoliko vprašljiva, saj so po nekaterih mnenjih stavko poskušali izkoristiti za pritisk na republiške in zvezne organe. A o tem je danes težko soditi, čeprav je Marinko po končani stavki dejal: »Zato, da bi se uveljavili, so vodilni ljudje ustvarili psihozo, ki so jo znali izkoristiti negativni elementi. Rudarje so pridobili za štrajk. Danes je razpoloženje rudarjev takšno, da je ves kolektiv, razen krivcev, ki smo jih bili prisiljeni zamenjati ob splošnem odobravanju vsega članstva ZK v Trbovljah, naslednje dni, ko je šel na delo, spoznal, da so nasedli. Sramovali so se in so, da bi popravili, kar so lahko, 
nakopali 500 do 700 ton premoga dnevno več kot prej, čeprav so že v decembru dosegli rekordno visoko proizvodnjo.« (Skopec 2007, 36)

Kdaj in kako se je stavka začela, je skorajda nemogoče ugotoviti; nekje okrog 17.00 ure popoldne je informacija o prekinitvi dela, ki je ta dan zaradi vzdrževalnih delih že tako potekalo $\mathrm{v}$ manjšem obsegu, prišla iz jaška Pesko in se razširila v ostale predele rudnika. Republiški sekretariat za notranje zadeve je bil o tem obveščen ob 22.30. Direktor rudnika je bil očitno o dogodkih obveščen že med sejo SZDL, ki jo je zapustil, novica o stavki pa SZDL, kjer so ravno sestavljali delegacijo, ki naj bi še istega večera odšla intervenirat $\mathrm{v}$ Beograd za cene premoga, ni dosegla oziroma je delegacijo dosegla po poti. Vodja delegacije Jože Pikl je o tem, da se bodo cene drugi dan zagotovo dvignile, obvestil stavkajoče, a mu ti niso verjeli. Klic so sicer sprejeli v jašku, kjer se je »zakuhala stavka«. V hrastniškem delu rudnika je delo potekalo do jutra 14. januarja, ko se je zaustavilo tudi tam. Marinko je iz Ljubljane interveniral, da naj trboveljska ZK prične reševati nastali položaj, obljubil pa je tudi, da bo popoldan osebno prišel v Trbovlje. V rudniku je nato najprej delegaciji sindikata razložil, da zvezni izvršni svet ravno na ta dan rešuje težavo in da jim gmotne razmere ne omogočajo, da bi jim izplačali več kot 30 odstotkov plače kot nagrado. Delegacija se je zavedala, da to rudarjev ne bo zadovoljilo, zato je $\mathrm{v}$ jaških to številko povečala na 50 odstotkov in tako spravila rudarje na plano. Petitsočglava množica je tako pred improviziranim odrom poslušala Marinka, ki je, namesto da bi povedal, da so stvari urejene in trinajsta plača bo, pričel jecljati in govoriti o tem, da je bo samo pol. Množica je spoznal, da je bila pretentana »in težko si je zamisliti bolj vnetljive okoliščine « (Skopec 2007, 39). Eden izmed rudarjev je s sekiro presekal kabel Marinkovega mikrofona, medtem pa so prevrnili še njegov avtomobil. Kaos je bil še večji, ker je bil to plačilni dan in je bilo med množico tudi veliko žena, ki so prišle po moževo plačo. Ko je nekaj posameznikov zavpilo »Gremo nazaj v jamo!«, rudarjev nihče več ni mogel zaustaviti.

Do tedaj so rudarji tudi postavili svoje stavkovne zahteve, iz katerih je popolnoma jasno, da so jih sestavili ad hoc in brez predhodnega načrtovanja.

$\mathrm{V}$ tem trenutku je postalo jasno, da bo za zaustavitev stavke potrebna resnejša politična akcija. V Trbovlje je prišlo slovensko partijsko vodstvo, republiški sekretar za notranje zadeve Ivan Maček - Matija pa je v Trbovlje 
milici v pomoč poslal skupino tajnih policistov. Policija je sicer nadzirala situacijo v civilni opravi, a imeli so ukaz, da je potrebno vsak upor fizično zatreti. Maček je direktorju rudnika dejal tudi, da ima nedaleč na tovornjakih že pripravljene vojaške in policijske okrepitve. Ta grožnja je vodstvo rudnika streznila in skušali so dejavneje umiriti situacijo. Mačkove grožnje niso bile »iz trte izvite«, saj je Edvard Kardelj kasneje na plenumu CK ZKS to potrdil. Še isti dan je tako prišlo do sestanka centralnega delavskega sveta rudnika, ki so mu prisostvovali visoki republiški politiki. V sklepih delavskega sveta so večini rudarskih zahtev ugodili in tako je trboveljski rudnik 15. januarja ob 22.00 uradno ponovno pričel z delom. Stvari pa so se zakomplicirale, ker je v tem času izbruhnila solidarnostna stavka $\mathrm{v}$ rudniku premoga Zagorje v neposredni bližini, in s podobnimi ukrepi kot $\mathrm{v}$ Trbovljah so v Zagorju uspeli situacijo pomiriti do 16. januarja zvečer.

Stavke se je v rudniku Trbovlje-Hrastnik udeležilo okoli 4.000 delavcev od 4.200 zaposlenih, v Zagorju pa približno polovica 2.400-članskega kolektiva. V naslednjih letih lahko opazimo, da se je ekonomsko-socialna situacija rudarjev drastično izboljšala, ceno za stavko pa je na koncu plačalo predvsem vodstvo, in to ne le rudniško. Po več sejah na različnih forumih je tako konec leta 1958 vodenje rudnika prevzel nov direktor Stane Dolanc, ${ }^{3}$ stolček se je majal tudi Mihi Marinku. Po nalogu Tita so prevetrili tudi sindikalna vodstva, zvezno sindikalno centralo je zapustil Djuro Salaj, ki ga je zamenjal stari komunist Svetozar Vukmanović Tempo. V Zasavju je prišlo do menjave vodstev lokalnih ZK, razpustili so tudi nekaj aktivov, več posameznikov je obravnavala milica in so bili krajši čas pridržani. Predvsem pa je, metaforično rečeno, »jugoslovanski socializem izgubil nedolžnost« in odprla se je pandorina skrinjica. O slednji se sicer ni javno poročalo, kljub nekaj minornim odmevom po Sloveniji, o katerih je poročala uprava državne varnosti, ne pa tudi mediji, saj je Marinko na plenumu CK ZKS 24. januarja dejal, »da so ti dogodki prodrli šele včeraj v javnost in je tržaški radio šele včeraj objavil prvo vest o stavki v Trbovljah« (Marinko 1984, 266).

To je zaznal sam vrh, saj je o tem v samokritični maniri govoril tudi Josip Broz Tito v uvodu na seji IK CK ZKJ prve dni februarja v Beogradu: »Trboveljski dogodki odpirajo probleme, ki se v bolj ali manj ostri obliki kažejo $\mathrm{v}$ vseh republikah $\mathrm{v}$ raznih oblikah in ki nas opozarjajo na resen slabosti v delu Zveze komunistov, sindikatov in naših gospodarskih organov. Tovariši iz Slovenije so trboveljske dogodke analizirali, vprašanje osvetlili v glavnem dobro, čeprav je bila njihova kritika okrenjena nekoliko preveč

3 Oče kasnejšega visokega zveznega funkcionarja Staneta Dolanca. 
navzdol in premalo navzgor. Gre predvsem za kritiko slabosti in napak nas samih.« (Zaznamek, 1958, 83)

\section{Razmah kolektivnih sporov}

Tako se je odprlo obdobje sproščanja konfliktov, ki je trajalo skozi celotna 6o. leta. Uradnega stališča do stavk pa jugoslovanska politika ni uspela sprejeti, po izbruhu stavke v Trbovljah je bil na VII. kongresu ZKJ sprejet nov program, ki je praktično prekinil z leninističnim dojemanjem partije, a v njem ni bilo nobenega eksplicitnega stališča do stavke. Dokument sicer precej idealistično obravnava družbene razmere, a vendar priznava, da družbenopolitična ureditev v Jugoslavije ne predstavlja »harmonične socialne simbioze« ter da v sami strukturi obstaja več ekonomskih, razrednih in političnih protislovij, ki lahko $\mathrm{v}$ določenih pogojih dobijo tudi antagonistični značaj. S tem je bila vsaj nakazana realna možnost, da lahko tudi v Jugoslaviji pride do konfliktov, kakršna je stavka. ZKJ je sicer o tem pojavu prvič javno razpravljala šele leta 1969 (Kavčič idr. 1991, 81).

A težava je obstajala in če poročil o stavkah sicer ne najdemo na naslovnicah časopisov, to ne pomeni, da jih ni bilo. V začetni fazi so se s pojavom stavke seveda ukvarjali predvsem organi za notranje zadeve, ki v javnost niso posredovali niti najosnovnejših informacij. Podatki o stavkah so bili prvič objavljeni šele leta 1964, ko so stavke pričeli spremljati sindikati po posameznih republikah. Prvi članek o stavkah je bil sicer objavljen že leto dni po prvi registrirani stavki, a je avtor z njim poskušal le na splošno dokazati nekompatibilnost stavke $\mathrm{z}$ »udejanjenim samoupravljanjem «. Prvi pravi članek, ki je obravnaval in zaznaval pojav stavk, je bil objavljen leta 1964, sledili pa so mu mnogi prispevki, predvsem s polja sociologije. V okviru raziskav so tako pričeli z empiričnim zbiranjem podatkov in analizami. A tudi tu so obstajali problemi, vezani na politično občutljivost tematike in težavnost zbiranja terenskih podatkov. Slovenski sindikati so tako leta 1969 prenehali zbirati podatke o stavkah, ker jih je bilo baje premalo, ponovno so se tega lotili šele leta 1973. Začetnik preučevanja stavk na jugoslovanskem nivoju je bil Neca Jovanov, ki je preučeval problematiko na podlagi podatkov sindikatov ter o tej temi objavil več del, sledili so mu še drugi (Kavčič idr. 1991, 89, 98).

Izsledki teh raziskav, ki so bili za slovenski primer v času »sproščanja konflikta« objavljeni v delu Kolektivni spori na območju SRS (1964-1966), kažejo, da pojav ni bil zanemarljiv. V obravnavanih letih je slovenska sindikalna centrala tako zaznala 114 stavk (skupna številka registriranih stavk 
za Jugoslavijo med 1958 in 1969 je sicer 512), od tega tudi 5 takšnih, ki so se zgodile v negospodarstvu. Logično je, da je bilo več kot tri četrtine stavk v industriji in rudarstvu, a tudi med ostalimi gospodarskimi dejavnostmi ne moremo najti dejavnosti, kjer se ne bi zgodila vsaj ena "prekinitev dela«. To je povezano tudi $z$ dejstvom, da je bil delež zaposlenih $v$ teh dejavnostih vse večji, padala pa sta deleža zaposlenih v težki industriji in rudarstvu, ki se je po drugi strani znašlo v krizi zaradi zmanjšanih investicij vanj ter posledično tehnične zastarelosti. Toda več kot 90 odstotkov teh stavk je imelo za neposredni vzrok problem delitve in višine osebnih dohodkov ter tehnične probleme produkcije, se pravi norme. Niso pa te stavke bile dolgotrajne ali množične, $v$ povprečju so zajele manj kot 100 delavcev in trajale približno 3 ure. Če vemo, da se stavke navadno začnejo v razvitejših okoljih, potem je logično, da se je pojav »prekinitev dela« širil s severa proti jugu države, kjer so stavke rudarjev na Kosovu pravzaprav označevale konec nekdanje skupne države in imele politični značaj (Mohar 1986, 6). Stavke so, tako kot je zapisano v uvodni pesmi, potekale večinoma v ožjih delovnih organizacijah in se niso razširile izven proizvodnih površin, v kakšnih 10 \% pa so to navadno represivno preprečili. Sindikat je kot del družbenopolitičnega sistema navadno ostal pasiven, stavke pa so večinoma zajele le proizvodne delavce, ne pa višje pozicioniranih kadrov. Tudi odnos samoupravnih organov do stavke je bil lokalno omahljiv, podobno kot na politični ravni

\section{Obdobje omejevanja konfliktov}

Mnogo zanimivejše obdobje je pravzaprav v času, ko je jugoslovanski standard rasel, torej $\mathrm{v}$ sedemdesetih letih. V študiji o stavkah govorijo o »obdobju omejevanja konfliktov«. V sedemdesetih letih je najprej z amandmaji na ustavo in nato novo ustavo leta 1974 prišlo do najkompleksnejšega urejanja družbenopolitičnih odnosov na slovenskih tleh v zgodovini. V vseh do potankosti opisanih načinih za urejanje delavskih zahtev, ki so bile zapisane v Zakonu o združenem delu, pa o stavki ni bilo zapisanega nič. S tem je Jugoslavija dejansko kršila mednarodni pakt o ekonomskih, socialnih in kulturnih pravicah, ki ga je ratificirala. $\mathrm{V}$ tem dokumentu je namreč nedvomno zapisano, da morajo imeti delavci držav podpisnic "pravico do stavke« v skladu z interno zakonodajo. Problem konfliktov je sicer načeloma pokrivalo poglavje Zakona o združenem delu (členi 636 do 640) $\mathrm{z}$ naslovom »Reševanje sporov, ki jih ni bilo mogoče rešiti po redni poti«. »Večina stavk se pri nas pod imenom prekinitev dela, izsiljeni sestanek, nezadovoljstvo delavcev ipd., tolerira po načelu: kar ni prepovedano, je dovo- 
ljeno. Reševanje pa je prepuščeno razmeram moči v organizacijah in morda še lokalnim občinskim predstavnikom.« (Mohar 1986, 13) Sedemdeseta leta so bila tudi politično nekoliko občutljivejši čas, saj ga poznavalci stvarnosti druge jugoslovanske države poznamo pod imenom »svinčena leta«, kot čas zaostritve političnih stališč, ki je sledila obračunom z liberalnimi in preveč nacionalističnimi republiškimi vodstvi, ena od najprizadetejših skupin pa so bili t. i. tehnokrati, gospodarstveniki. Ti so bili pred tem znani po tem, da so večji poudarek dajali gospodarski učinkovitosti kot pa političnim ciljem (Prinčič 2008).

A problemi so ostajali podobni kot $\mathrm{v}$ času prve stavke $\mathrm{v}$ Jugoslaviji. Pred seboj imam obsežen dokument $\mathrm{z}$ naslovom Politična ocena vzrokov prekinitve dela $v$ TOZD - proizvodnja premoga v OZD Rudnika lignita Velenje. Stavka je izbruhnila 12. aprila 1973 ob 14.00 in je trajala do naslednjega dne do 14.30. Vzroki, ki so do nje pripeljali, so segali vsaj v obdobje 1966/1967, ko je v Jugoslaviji vladala gospodarska recesija. To je še posebno močno občutilo gospodarstvo, saj je potrošnja premoga močno upadla. V rudniku Velenje so bili proizvodnjo prisiljeni drastično zmanjšati. Tedaj so morali odpustiti 500 delovno najsposobnejših rudarjev, ki so se bili sposobni prezaposliti. Osebni dohodki rudarjev so se zmanjšali za dobrih 40 odstotkov. Leta 1968 se je položaj na trgu normaliziral, a novih rudarjev niso uspeli dobiti dovolj. Konstantno je primanjkovalo 100 do 200 delavcev, kar je povzročalo proizvodne težave. Rudnik je istočasno ugotovil, da bi bilo za njegovo poslovanje najboljše, če bi izkopani lignit na licu mesta uporabili v novi termoelektrarni Šoštanj, v katero je vložil večino svojih prostih sredstev iz amortizacije. Zaradi tega niso bili sposobni vlagati v obnovo samega rudnika, niso pa bili niti sposobni najeti potrebnih kreditov. Zato je uprava rudnika pritiskala, da bi premog iz Velenja lahko prodajali po višji ceni. Istočasno je v okolici začela rasti predelovalna industrija (Gorenje), kjer so bili delovni pogoji lažji, plače pa le za dobrih 10 \% nižje. Rudnik se je posledično začel soočati s pomanjkanjem rudarjev, ki jih je nato iskal po celi Jugoslaviji. Fluktuacija delovne sile je bila velika, v enem letu se je zamenjala od tretjina do četrtine vse delovne sile (9oo zaposlenih). Naložba $\mathrm{v}$ termoelektrarno ob nizkih cenah energije ni vračala sredstev oziroma je rudnik moral pokrivati še izgubo, prihodnost rudarstva pa je bila vse bolj problematična. Delavstvo v rudniku je tako bilo prisiljeno delati več za manjše dohodke, posebej problematična je bila uvedba sobotnega dela, velika fluktuacija delavstva pa je povzročala tudi težave socialne narave, predvsem stanovanjske. $\mathrm{Na}$ zborih aktivov, ki so se zbrali v okviru reše- 
vanja stavke, so poleg tega poudarjali, da so bile zahteve rudarjev deloma upravičene, a še več je bilo "poskusov podtikanja, zlonamernega namigovanja, parolarstva, nekonstruktivne kritike, neverjetno močno pa je bila prisotna uravnilovka in ,teorija enakih želodcev'“ (SIKVEL, Politična ocena).

Sama stavka je izbruhnila po povsem enakem receptu, »cca. 10 zaposlenih na koti 30 čela A je začelo spraševati tehničnega vodjo obrata ing. Oblak Zdravka o tem, kako je z ureditvijo osebnih dohodkov«. Z odgovori niso bili zadovoljni, nakar so naslednji dan ponovno intervenirali, tretjič pa ostali v jami, kjer so jim 12. aprila dopoldan inženirji po jaških razlagali o finančni situaciji. Prepričevanja pa so bila neuspešna in popoldan se je »izsiljeni sestanek« spremenil v prekinitev dela. Zgolj za zanimivost naj dodam, da je bila ena od rudarskih zahtev tudi, da naj se o situaciji v rudniku Velenje seznani »tovariša Tita«. V prvi izmeni je stavkalo med 400 in 500 rudarjev, med njimi precej tudi članov $\mathrm{ZK}$, kmalu so pričeli prihajati tudi drugi, glas o stavki pa je segel tudi v rudnik svinca v Mežici, kjer so se s stavko solidarizirali. Vodstvo rudnika in družbenopolitični organi so poskušali »kričače«izolirati tudi tako, da so člani ZK med zbranimi »opravili proces notranje diferenciacije«. Vmes je potekala izredna konferenca rudniške ZK, kjer so sprejeli več sklepov, ki so rudarskim zahtevam ugodili. »Na koncu je direktor rudnika zagotovil, da se bodo sprejeta stališča zagotovo uresničila, saj stoje za njimi vsi komunisti rudnika, predsedstvo RO sindikata in najodgovornejši organi republike. /.../ Navzoči so z aplavzom sprejeli stališče konference.« (SIKVEL, Politična ocena) Analiza vzrokov je pogojevala kopico akcij, ki so jih $\mathrm{v}$ naslednjih mesecih delegirali različnim sektorjem, zajemale pa so tako uskladitev cen avtobusnih vozovnic kot tudi izboljšanje informiranja in preprečevanje ustvarjanja konfliktnih situacij. O sankcijah v poročilu ni govora.

Obdobje »omejevanja konfliktov« ima še eno značilnost. Spremembe so posledica dušenja konfliktov, ki so nastajali konec šestdesetih in $\mathrm{v}$ začetku sedemdesetih let, ko so je povečevala avtonomna vloga republik ter gospodarskih in družbenih organizacij. V sedemdesetih letih se uradna stališča do stavke niso spremenila, toda $\mathrm{v}$ primerjavi $\mathrm{z}$ drugo polovico šestdesetih let so bile ponovno močneje prisotne težnje, da bi stavke prikrili, če že ne preprečili. Zakon o združenem delu je zato omogočal označitev stavke za »kršitev delovne obveznosti« oziroma »kršitev samoupravljavske funkcije«. Za predčasno odkrivanje in preprečevanje takšnih konfliktov 
so poleg drugih, danes manj spornih funkcij ${ }^{4} \mathrm{v}$ kolektivih skrbeli komiteji za splošno ljudsko obrambo in družbeno samozaščito (Janša 1986, 40). Preprečevanje stavk je bilo tako del nalog državnega obrambnega sistema, ki pa na tem polju ni bil najbolj uspešen (Kavčič idr. 1991, 85). Število stavk je namreč še vedno ostalo relativno visoko, med avgustom 1973 in septembrom 1974 jih je bilo tako v Sloveniji 44, od leta 1974 do 1976 pa kar 161.

\section{Eskalacija konfliktov}

Konec sedemdesetih let je gospodarski položaj v Jugoslaviji začel kazati znake resnih težav, ki so jo jih do smrti predsednika Tita maja 1980 deloma poskušali prikrivati. Kmalu zatem je nastopilo obdobje, ki mu lahko rečemo le družbena in ekonomska kriza. Znašli smo se $\mathrm{v}$ »obdobju sproščanja konfliktov«. S ponovnim poudarjanjem pomena tržne ekonomije $\mathrm{v}$ nasprotju $\mathrm{z}$ »dogovorno ekonomijo « so se pričele spreminjati vrednote. Za razliko od prej navedenih sprememb pa lahko ugotovimo, da so te ideološke orientacije mnogo počasneje spremljale institucionalne spremembe in se je stara struktura iz sedemdesetih let praktično ohranila vse do konca obstoja Jugoslavije. Novi zakon o podjetjih, ki je uvajal tržno gospodarstvo, je bil tako v uradnem listu objavljen na silvestrovo 1988 (Žerdin 2016). V času najhujšega zategovanja pasov, ko je bila država praktično pod upravo Mednarodnega denarnega sklada in je vlada Milke Planinc standard državljanov za dotedanje jugoslovanske razmere pripeljala na dno, je bilo število stavk podobno kot ob koncu sedemdesetih let. Eskalacija stavk v Jugoslaviji je pričela v letu 1985, ko je bil siceršnjega zategovanja pasu pod novo vlado Branka Mikulića konec. Gospodarski sistem se je zapletal sam vase, delavski dohodki so postajali vse bolj pereče vprašanje. $\mathrm{V}$ drugi polovici osemdesetih let so raziskovalci stavk ugotovili, da sta se obseg in intenziteta stavk drastično povečala, stavke so postajale vse bolj množične in daljše. Stavke, o katerih je bilo govora v prejšnjih obdobjih, so navadno zajele dele delovnih organizacij in so bile kratke. $V$ tem času pa že lahko govorimo o tem, da so stavke zajele celotne organizacije, vse več je bilo pojavov solidarnostnih stavk, stavk celotne panoge in prvi poskusi generalnih stavk. Glavni in edini vzrok za stavko pa je bil še vedno višina osebnih dohodkov. Pomembna pa je bila tudi sprememba percepcije vzrokov: stavke so bile vedno pogosteje naperjene proti dejavnikom zunaj delovnih organi-

Obrambni sistem izven vojaških okvirov je bil v Jugoslaviji tudi podružbljen in komiteji so bili v vsaki osnovni celici družbe ter so združevali vse ostale oblike obrambe. 
zacij, proti različnim sistemskim institucijam, kar se je izkazovalo v danes najobičajnejšem prizoru, demonstrativnem odhodu pred skupščine, lokalne ali republiške. Stavke so v letih 1988-1989 na republiški ravni zajele približno 7 odstotkov vseh delovnih organizacij (Kavčič idr. 1991, 122, 128-29). Pomembna sprememba je bila tudi postopno krušenje obstoječega družbenopolitičnega sistema, ki se je izkazovala v pojavu novih sindikatov. Pred tem edini sindikat, ki je bil praktično podaljšana roka države, je dobil konkurenco, zato se je pričelo povečevati število stavk, kjer so sindikati dejansko podprli stavkajoče, ne pa stavk poskušali umirjati. Stavkajoči so tudi pričeli z organizacijo stavkovnih odborov, ki so artikulirano podajali zahteve, kar je bil vsaj pri manjših "prekinitvah dela« nov precedens.

Predvsem pa je stavka po dolgotrajnih opozorilih v Jugoslaviji in nato še Sloveniji dobila domovinsko pravico (Kuzmanić 1986, 15). V ustavnih amandmajih k Ustavi SFRJ iz leta 1988 in nato $\mathrm{v}$ amandmajih $\mathrm{k}$ Ustavi SRS iz leta 1989 je bila pravica do stavke povzdignjena v ustavno pravico. Marca 1991 je tako Polona Končar lahko zapisala, »da je stavka postala individualna pravica delavcev, ki se uresničuje kolektivno. /.../ Titular pravice do stavke je delavec in ne sindikat«. (Končar 1991, 7-9)

Toda za razumevanje mejnikov je potrebno nekoliko podrobneje pogledati še eno stavko, ki je, gledano z današnje, nekoliko oddaljene perspektive spremenila slovensko družbo. Stavka delavcev ljubljanskega podjetja Litostroj, industrijskega giganta, ki je v tistih časih še ponosno nosil ime Titovi zavodi, je bila pomembna prelomnica, verjetno večja kot trboveljski dogodki trideset let prej. Vzrok za stavko so bili, tako kot vedno, osebni dohodki. A Litostroj je leta 1987 doživel šok, ko je zaradi nelikvidnosti z novimi ukrepi zvezne vlade doživel blokado žiroračuna. To je bila povsem nova situacija za podjetje, ki je velik del izgub v prejšnjih letih nakopičilo zaradi nerednih plačil iz Iraka. V Jugoslaviji je bila ta čas izredno visoka inflacija in nominalno so se plače povečevale iz meseca v mesec. Poleti 1987 delavci prvič niso prejeli do tedaj običajnega desetodstotnega dodatka. Plače so ostale zamrznjene skozi celotno leto in decembra 1987 je zavrelo. Stavka je izbruhnila v brusilnici, ko je delavec ob 7.00 zjutraj ob pogledu na plačilno listo dejal, da za 200 nemških mark ne bo več delal, sploh pa ne za 184 ur na mesec. Stroji so se ustavili, glas se je prenesel skozi naslednje obrate, delavci pa niso hoteli več poslušati delovodij, ki so jih poskušali zadržati na delovnih mestih. Kasneje se je izkazalo, da so enega od obratov v poskusu izolacije tudi zaklenili z zunanje strani. To ni bila prva prekinitev dela $\mathrm{v}$ tem podjetju, a nekaj let pred tem so stavkali le »modri ovratniki«, ki se jim teh- 
nični kader ni pridružil. Tokrat je bilo drugače in delavci so se pričeli zbirati pred upravno stavbo. $O$ dogajanju so bili hitro obveščeni tudi mediji. Stavkajoči so zahtevali, da prednje stopi novoimenovani direktor, ki pa ga ni bilo. $V$ protestu je množica odšla pred stavbo občine, tam pa je spontano zavila proti središču mesta in pred skupščino.

Tu se je dogajanje zaostrilo, nekdanji sindikalist France Tomšič se je samoiniciativno, po mlačnih pozivih vodje sindikata, da naj stavko prekinejo, dokopal do megafona in začel organizirati stavko, poskušal je izvoliti stavkovni odbor. Tedaj sta k njemu pristopila dva civilno oblečena policista, uniformirani pa so se skrivali v preddverju današnjega slovenskega parlamenta za Tomšičevim hrbtom. Prepričala sta ga, da megafona ni dobro slišati in da je potrebno zamenjati baterije. S to pretvezo so nastajajoči stavkovni odbor spravili v poslopje republiške skupščine, kjer so baterije nato iskali skoraj pol ure. Množica pred skupščino je menila, da so jih pridržali, zato je prodrla na drugo stran ceste in zasedla največjo dvorano v osrednjem kulturnem prizorišču v državi, v Cankarjevem domu. Tomšič in ostali iz skupščine so se jim kmalu pridružili in pred petisočglavo množico se je začela odvijati organizirana stavka. Pred stavkajočimi se je tokrat pojavil tudi generalni direktor, ki je poskušal množico pomiriti z obljubo o 20-odstotnem povečanju plač, a je bil izžvižgan. Stavkovni odbor je sestavil stavkovne zahteve, stavka uradno ni bila prekinjena, a naslednji dan se je delo $\mathrm{v}$ podjetju normalno nadaljevalo. Vodstvo podjetja je določene zahteve do tedaj sprejelo in stavkovnemu odboru med sestankom sporočilo, da zanj ne obstaja več, saj so se delavci vrnili na delo. Naleteli pa so na nekoliko bolj trdoglave nasprotnike, kot so bili pričakovali.

15. decembra je na zborovanju delavcev stavka prešla $\mathrm{v}$ politični obračun z obstoječim redom in ustanovljena je bila prva opozicijska politična stranka v socialističnem bloku, Slovenska demokratska zveza. Povezala je različne opozicijske sile, bila pa je tudi legalna, saj se je kot zveza lahko tudi uradno registrirala (Tomšič 2010, 143-98). V kombinaciji s pravico do ustanavljanja neodvisnih sindikatov je to pomenilo prvo resno razpoko v slovenskem družbenopolitičnem prostoru, stavka pa je dejansko dobila pomen, ki ga $\mathrm{v}$ preteklih in niti naslednjih obdobjih ni imela - postala je izrazito politično dejanje.

\section{Zaključek}

Na podlagi povedanega lahko zaključimo, da so bile delavske stavke $v$ času socialistične Jugoslavije dokaj pogost pojav. Uradno so o njih govorili kot 
o prekinitvah dela in niso bile sredstvo, ki bi ga kompleksni jugoslovanski socialistični samoupravni sistem pripoznaval kot legitimen del političnega udejstvovanja. V načelu je bila stavka problematična tudi z vidika, da so delavci uradno vplivali na vse pomembne odločitve $s$ splošno udeležbo $\mathrm{v} t$. i. samoupravnih procesih. Stavke so večinoma nastajale spontano in niso imele opore v sindikalnih organizacijah, ki so bile del državnega aparata. Stavke so tako sicer napadale družbenopolitični sistem s tem, da so posredno kritizirale njegove temelje, vendar sistemu niso predstavljale resnejše grožnje. Število stavk je bilo v obravnavanem obdobju zares veliko, a njihova frekvenca je bila odvisna tudi od spreminjajočih se družbeno-ekonomskih okoliščin. Zaradi tega ne preseneča ugotovitev, da je pravi stavkovni val z resnejšim političnim značajem zaznamoval predvsem konec osemdesetih let prejšnjega stoletja, ko se je vse bolj jasno nakazovala jugoslovanska politična in gospodarska kriza.

Prispevek je nastal v okviru raziskav, sofinanciranih iz raziskovalnega programa ARRS P6-0281 »Idejnopolitični in kulturni pluralizem in monizem na Slovenskem v 20. stoletju«.

\section{Viri in literatura}

Arhivski viri

SIKVEL: Knjižnica Velenje.

Politična ocena vzrokov prekinitve dela v TOZD - Proizvodnja premoga (PP) v OZD Rudnika lignita Velenje, Ocena in sklepi družbenopolitičnih organizacij Rudnika lignita Velenje v zvezi s stavko rudarjev leta 1973.

\section{Objavljeni viri}

Marinko, M. 1984. Izbrana dela 3. Ljubljana: Komunist.

Mlakar, I. 1992. "Pubi, usidma se.« Št. 5 na Štorije in baldorije. ZKP RTV Slovenija, avdiokaseta.

Zakon o združenem delu. 1976. Uradni list SFRJ, 53 (1976).

Zaznamek o razširjeni seji Izvršnega komiteta CK ZK Jugoslavije, ki se je vršila v Beogradu, dne 6. II. 1958. 2007. V Dokumenti o rudarski stavki v Zasavju leta 1958, ur. R. Podberšič in D. Hančič. Ljubljana: Ministrstvo za pravosodje Republike Slovenije. 
Žerdin, A. 2016. »Imamo kapitalizem. Imamo tudi razrede? Kapitaliste? Proletariat.« Delo, Sobotna priloga, 1. oktober 2016, str. 12-13.

\section{Literatura}

Brečko, D., N. Mikić Bulc, M. Švab in P. Vindišat 1973. Samoupravni sporazumi o združevanju temeljnih organizacij združenega dela. Ljubljana: Republiški svet sindikatov Slovenije in Raziskovalni center za samoupravljanje RS ZSS.

Čepič, Z. 2005. "Delavska ustava.«V Slovenska novejša zgodovina: od programa Zedinjena Slovenija do mednarodnega priznanja Republike Slovenije: 1848-1992, ur. J. Fischer idr., 1099-101. Ljubljana: Mladinska knjiga in Inštitut za novejšo zgodovino.

Čepič, Z. 2011. "Načela in počela socialistične demokracije.«Prispevki za novejšo zgodovino 51 (1): 271-69.

Janša, J. 1986. »Stavka kot mejno dejanje.« Časopis za kritiko znanosti 93/94: 39-44.

Kavčič, B., A. Lukan, D. Mesner-Andolšek in A. Čibron-Kodrin (ur.) 1991. Stavke. Ljubljana: Znanstveno in publicistično središče.

Končar, P. 1991. »Stavke in njihova regulacija v razvitih državah in pri nas.» V Stavke, ur. B. Kavčič, A. Lukan, D. Mesner-Andolšek in A. ČibronKodrin, 7-9. Ljubljana: ZRS.

Kržišnik Bukić, V. 1991. Cazinska buna 1950. Sarajevo: Svjetlost.

Kuzmanić, T. 1986. »Za legalizacijo štrajkov.« V Časopis za kritiko znanosti 93/94: 15-28.

Mohar, L. 1986. »Stavka - da ali ne?« Časopis za kritiko znanosti 93/94: 3-14.

Prinčič, J. 1992. Slovenska industrija v jugoslovanskem primežu. Novo mesto: Dolenjska založba.

Prinčič, J. 2005. »Dogovorna ekonomija.« V Slovenska novejša zgodovina: od programa Zedinjena Slovenija do mednarodnega priznanja Republike Slovenije: 1848-1992, ur. J. Fischer et al., 1101-104. Ljubljana: Mladinska knjiga in Inštitut za novejšo zgodovino.

Prinčič, J. 2008. »Direktorska funkcija v jugoslovanskem socialističnem gospodarskem sistemu." V Biti direktor v času socializma: med idejami in praksami, ur. J. Fikfak in J. Prinčič, 57-101. Ljubljana: ZRC SAZU.

Skopec, D. 2007. »Stavka v rudnikih Trbovlje-Hrastnik in Zagorje od 13. 1. 1958 do 16. 1. 1958." V Dokumenti o rudarski stavki v Zasavju leta 1958, 
ur. R. Podberšič in D. Hančič, 1-76. Ljubljana: Ministrstvo za pravosodje Republike Slovenije.

Šuvar, S. 1984. »Samoupravljanje od prvog radničkog savjeta do stvaranja društva udruženog rada.«V Prvi radnički savjet, ur. D. Grgurević, 33-42. Split: Institut za historiju radničkog pokreta Dalmacije.

Tomšič, F. 2010. Od stavke do stranke. Nova obzorja: Ljubljana.

\section{Summary}

"We have no strikes in Yugoslavia, there are only some occasional self-managed work interruptions." Strikes in socialist Slovenia

Worker strikes were a common phenomenon in socialist Yugoslavia, although they officially never existed. They were called work interruptions and were not something that the complex Yugoslav self-managed socialism recognised as part of a political struggle since workers officially influenced all major decisions through the so-called self-managing process. These strikes were mostly spontaneous and without back-up from the state and the party-controlled syndicates. The strikes were prompted by the dissatisfaction with the distribution of profit which was not used for basic investments and living standards of the workers since it was spent for other capital investment, as determined by higher self-management administrative bodies. Strikes were, therefore, attacking the system by criticizing its own foundations, but not seriously endangering it. The number of strikes was relatively high, their number depending mostly on the changing conditions of the Slovene/Yugoslav economy, booming in the late 1980s when the word strike entered the official vocabulary once again. 